\title{
Wirpsza w niemieckim przekładzie, czyli z lingwizmu w konkretyzm ${ }^{\text {r }}$
}

\section{Wirpsza w przekładzie}

Pośród wydanych za granicą książek przekładowych Witolda Wirpszy można znaleźć tomik brucbsünden und todstücke ${ }^{2}$. Ten niewielki wybór utworów autora w tłumaczeniu Marii Kureckiej został opublikowany w Stuttgarcie w roku 1967. Książka ukazała się jako trzydziesty pierwszy numer serii publikacyjnej „rot”, redagowanej przez Maksa Bensego i Elisabeth Walther. Seria ta ściśle wiązała się z ruchem konkretystycznym, o czym świadczy choćby zamieszczona na końcu tomiku Wirpszy lista innych wydanych w „rot” tytułów, pośród których pojawiają się antologie i prezentacje indywidualne konkretystów. Nieprzypadkowo także drukiem książki Wirpszy zajmował się Hansjörg Mayer, słynny typograf współpracujący z poetami tego nurtu.

Tomik Wirpszy wypada dość nietypowo na tle dominujących ówcześnie wydawnictw poetyckich. Publikacja ma bowiem broszurowy wygląd, niewielki kwadratowy format i miękką, czerwoną okładkę, przypominającą projektowane masowo etykiety, reklamy i ogłoszenia. Projekt ten, użyty w kontekście poezji, zdaje się modyfikować jej „wysoki” status. W książce pojawiają się zresztą błędy zecerskie, a bardzo niewielkie marginesy dodają wrażenia surowości. Jeszcze istotniejsze są takie cechy opracowania graficznego, jak pogrubiona Helvetica, popularny bezszeryfowy krój pisma, charakterystyczny dla powojennego modernistycznego projektowania graficznego, nieraz stosowa-

\footnotetext{
${ }^{\text {I }}$ Artykuł powstał $\mathrm{w}$ ramach projektu sfinansowanego ze środków Narodowego Centrum Nauki przyznanych na podstawie decyzji numer DEC2011/01/N/HS2/03906.

${ }^{2}$ W. Wirpsza, bruchsünden und todstücke, thum. M. Kurecka, red. M. Bense, E. Walther, „rot” 31, Stuttgart 1967. Dalej odnoszę się tylko do tego (jedynego) wydania książki, które ma nienumerowane strony. Ze względu na istotną rolę wydawnictw dla poruszanej przeze mnie problematyki w adresach bibliograficznych podaję nazwy oficyn.
} 
nego w reklamie. Znika także Wirpszowe rozróżnienie na teksty pisane $\mathrm{z}$ zachowaniem wielkich liter $\mathrm{i}$ ich pozbawione. $\mathrm{W}$ tomiku wszystko zanotowane jest minuskułą, zgodnie z postulatem rzeczników stylu szwajcarskiego w typografii, choćby Maksa Billa ${ }^{3}$. Podobne źródło ma wyrównany do lewej, asymetryczny, chorągiewkowy skład.

Tymczasem w oryginalnej wersji językowej zawartość bruchsünden und todstücke wygląda zupełnie inaczej. Wybrane do przekładu wiersze poety opublikowane były wcześniej w dwóch polskich tomikach Wirpszy: w Drugim oporze oraz w Przesadach, wydanych odpowiednio w roku 1965 w Czytelniku i w 1966 - w PIW-ie4. Zachowano $w$ nich wielkie litery oraz konwencjonalne dla książek poetyckich szerokie, białe marginesy, elegancki szeryfowy krój, prostokątny format i przynajmniej częściowo symetryczny skład. Polskie wersje tekstów, przygotowane przez duże i w pełni zinstytucjonalizowane wydawnictwa, nie mają nic z wyrazistości charakterystycznej dla współtworzonej przez artystów stuttgarckiej oficyny. Wygląd rodzimych wersji utworów jest kreowany jako autorytatywny, niewidzialny, niepodważalny, ukrywający wszelkie stadia pośrednie między rękopisem a drukiem książki 5 . Niemieckojęzyczna postać tekstów uwidacznia zaś ich uwikłanie, ich zależność od materiałów, mód, technik i kontekstów, a przede wszystkim od wielu zaangażowanych $\mathrm{w}$ proces publikacji osób ${ }^{6}$.

Polskie i niemieckie wersje wierszy różnią się zatem nie tylko językiem i wynikającymi z tego problemami przekładu literatury. Polskie i niemieckie książki umieszczają także poezję Wirpszy w zupełnie różnych kontekstach edytorskich, literackich i socjologicznych. Co więcej, mamy tu do czynienia z ingerencją w same utwory, skoro zmieniają na przykład zasady pisowni - już przez Wirpszę nieraz niekonwencjonalnie dobierane, a w „rot” dostosowane do ortografii i typografii charakterystycznej dla środowi-

3 Zob. np. M. Bill, max bill: typografie - reklame - buchgestaltung: typography - advertsing - book design, tłum. J.L. Walker, R. Thomas, Niggli Verlag, Zürich 1999.

4 W. Wirpsza, Drugi opór. Wiersze 1960-1964, Czytelnik, Warszawa 1965; W. Wirpsza, Przesady, PIW, Warszawa 1966.

5 Pierwsze wersje tekstów Witolda Wirpszy były pisane odręcznie - informację zawdzięczam Profesorowi Leszkowi Szarudze.

${ }_{6}$ Zarysowane przeciwstawienie przypomina proponowany przez Johannę Drucker podział na marked texts (nacechowane, wyraziście ukształtowane wypowiedzi typowe dla tekstów użytkowych) oraz unmarked texts (niewidzialne, nienacechowane - typowe dla literatury i nauki). Rozróżnienie to w pełni zaburzyli dopiero twórcy awangardowi, a potem poeci konkretni, którzy w swojej poezji stosowali typografię znaną z reklam i ogłoszeń (zob. J. Drucker, The Visible Word. Experimental Typography and Modern Art, 1909-1923, The University of Chicago Press, Chicago - London 1996, s. 94-96). 
ska stuttgarckiego. Teksty wyselekcjonowane do brucbsünden und todstücke są zresztą w sposób szczególny nacechowane wizualnie: posługują się nietypowymi spacjami i cięciami wypowiedzi, które dodatkowo podkreślają wagę określonego zapisu wiersza. $\mathrm{Z}$ tego względu jeszcze bardziej niemożliwe okazuje się precyzyjne oddzielenie problemów przekładu od problemów zapisu i druku, a w konsekwencji - również od samego wydania tekstów Wirpszy.

Wraz z tymi spostrzeżeniami pojawia się pytanie o cel i charakter takiego przeniesienia polskich horyzontów poezji eksperymentalnej z lat 60 . w kontekst niemieckojęzyczny, związany z rozwijającym się wtedy ruchem konkretystycznym i ideami poszerzania projektów literackich o modernistyczne kroje bezszeryfowe, kwadratowe okładki, kolor czarny, biały lub czerwony, styl szwajcarski w typografii itp. ${ }^{7}$. Wydaje się, że ten przekład wyobraźni - zaznaczony przez zmianę wyglądu książki, a dodatkowo uzasadniony specyficznym wyborem utworów Wirpszy, wyjątkowo podkreślających rolę przestrzeni - nie mógł być przypadkowy.

Publikacja niemiecka ukazała się zaraz po polskich tomikach Wirpszy, w przekładzie jego żony. Poeta, wiedząc o tym przedsięwzięciu, zgodził się na wpisanie swojej twórczości w nowe porządki, albo raczej uwidocznił mniej oczywiste perspektywy lektury swoich tekstów. Nazywam je mniej znanymi, ale nie nowymi, ponieważ i w innych przykładach aktywności Wirpszy

7 Intensywna współpraca poetycko-artystyczno-wydawnicza nie była rzecz jasna nowością, lecz powrotem do praktyk pierwszej awangardy, także niemieckojęzycznej, by przypomnieć choćby różnego rodzaju czasopisma dadaistyczne (zob. np. zbiory The InternationalDada Archive, http://sdrc.lib.uiowa.edu/dada/, dostęp: 17 grudnia 2012). Po wojnie zaś nie sami tylko konkretyści niemieckojęzyczni korzystali z możliwości wielorakiej współpracy poetycko-wydawniczej. W tym artykule skupiam się jednak wyłącznie na specyfice konkretystycznej działalności publikacyjnej, mocno związanej z wąskim, źródłowym rozumieniem poezji konkretnej. O niemieckiej koncepcji konkretyzmu, nietożsamej z późniejszymi angielskimi i polskimi wyobrażeniami na temat tak nazywanej twórczości, a także o relacjach konkretyzmu i awangardy piszę w artykule Poezja konkretna w trzech obszarach językowych („Przestrzenie Teorii” 2013, nr 19). Trzeba dodać, że ta konkretystyczna współpraca wydawnicza dawała znacznie mniej radykalne efekty niż utwory awangardowe. $Z$ tego też powodu była dotąd zwykle ignorowana w badaniach. Jeszcze inną kwestią jest niemal brak takiej współpracy artystów i projektantów z poetami eksperymentalnymi w Polsce w pierwszych powojennych dekadach - pomimo wielu udanych doświadczeń przedwojennych, tak futurystycznych, jak konstruktywistycznych i funkcjonalistycznych (na ten temat zob. zwłaszcza: P. Rypson, Ksiażki i strony. Polska ksiazika awangardowa $i$ artystyczna w XX wieku, Centrum Sztuki Współczesnej Zamek Ujazdowski, Warszawa 2000, s. 93-94; liczne reprodukcje polskich przedwojennych tomików poetyckich można także znaleźć w: idem, Nie gęsi. Polskie projektowanie graficzne 1919-1949, Wydawnictwo Karakter, Kraków 2011). 
da się znaleźć powinowactwa z zainteresowaniami i działalnością Grupy Stuttgarckiej oraz poetów konkretnych. Przekład podbudowuje zatem możliwość czytania Wirpszy w nowym świetle, zachęca do badań komparatystycznych, do zestawiania utworów poety $\mathrm{z}$ innymi publikacjami, nad którymi pracowano w Stuttgarcie w roku 1967. Takie wyjście poza kontekst ówczesnej literatury polskiej, wyjście poniekąd zaproponowane przez samego poetę, wydaje się ważnym tropem, zgodnym z pozostałymi decyzjami Wirpszy: o wydaniu i innych jego książek w języku niemieckim ${ }^{8}$, o emigracji do Berlina Zachodniego ${ }^{9}$, o przekroczeniu ograniczeń poetyk dominujących w Polsce nurtów literackich, a nawet wcześniejszych propozycji rodzimej awangardy ${ }^{\mathrm{ro}}$.

Omawiany przekład utworów Wirpszy nie jest jednak samym tylko przyczynkiem do studiów porównawczych. Publikacja ta, traktowana całościowo jako nowa książka podpisana przez polskiego autora, przynależy bowiem do historii Grupy Stuttgarckiej i serii „rot”. Bliższe przyjrzenie się specyfice ruchu konkretystycznego w krajach niemieckojęzycznych, zwłaszcza kwestii publikacji seryjnych, uwidacznia, że samo publikowanie w określonych projektach wydawniczych stanowiło swego rodzaju współuczestnictwo w ruchu. Książkę Wirpszy warto więc potraktować jako wydarzenie należące do historii literacko-artystycznej regionu, choć - trzeba przyznać - nie miało ono szerszego oddźwięku ${ }^{\mathrm{II}}$.

W dalszej części tekstu skupię się zatem na problemach związanych nie tyle $\mathrm{z}$ językowymi aspektami przekładu ${ }^{\mathrm{I2}}$, ile $\mathrm{z}$ jego

${ }^{8}$ Zob. np. tego autora: Orangen im Stacheldrabt (1967), Der Mörder: Erzäblungen (1971), Drei Berliner Gedichte (1976).

9 Wirpsza mieszkał na emigracji w Berlinie Zachodnim od 1971 r., czyli od czasu ataków polskiej prasy na poetę po publikacji zbioru esejów Pole, wer bist $d u$ ?; wcześniej Wirpsza wyjeżdżał na stypendia, między innymi do Austrii (zob. np. J. Grądziel-Wójcik, Poezja jako teoria poezji. Na przyktadzie twórczości Witolda Wirpszy, Wydawnictwo Naukowe UAM, Poznań 2001, s. 8).

то Zbigniew Chojnowski widział w twórczości Wirpszy pierwsze przekroczenie konserwatyzmu polskich awangard (zob. Z. Chojnowski, Wizja człowieka, wizja kultury. O poezji Witolda Wirpszy w latach sześćdziesiątych, „Integracje. Kultura - sztuka - literatura - życie artystyczne" 1992, nr 28, s. 20). O nowatorskości Wirpszy zob. też: A. Wiedemann, Witold Wirpsza - poeta trzydziestoletni, „FA-art” 1998, nr 1-2, s. 5-6; A. Kałuża, Wola odróżnienia. O modernistycznej poezji Jarostawa Marka Rymkiewicza, Julii Hartwig, Witolda Wirpszy i Krystyny Miłobędzkiej, Universitas, Kraków 2008, s. 34-48.

II Nie jest mi znana żadna wypowiedź w jakikolwiek sposób komentująca tę publikację.

${ }^{\text {I2 }} \mathrm{O}$ językowych aspektach tego przekładu piszę w artykule Book of translations as a self-commentary. On „bruchsünden und todstücke” by Witold Wirpsza („Prace Filologiczne. Literaturoznawstwo” 2012, nr 2). W tekście tym przedstawiam także oparte na kwestiach niepowiązanych z konkretyzmem argumenty na rzecz traktowania tomiku jako autokomentarza. 
kształtem wydawniczym, kontekstem artystycznym oraz z komparatystycznymi perspektywami badawczymi, do podjęcia których zachęca niemiecka publikacja.

\section{Konkretystyczne publikacje seryjne ${ }^{\mathrm{I} 3}$}

Seria „rot” nie należała do wyjątków na tle działalności ruchu konkretystów w krajach niemieckojęzycznych. Podobnie pomyślane publikacje powstawały $\mathrm{w}$ różnych ośrodkach: $\mathrm{w}$ okolicach Zurychu i Gomringerowskim wydawnictwie we Frauenfeld, w Kole Darmstadzkim czy właśnie w Grupie Stuttgarckiej. W każdym z tych miejsc ukazywały się serie broszur, zeszytów czy książek, między którymi podziały okazują się płynne. Znamiennym śladem niejasnego statusu tych publikacji są wskazujące na nie odniesienia bibliograficzne, które raz sugerują, że mamy do czynienia $\mathrm{z}$ czasopismem, a innym razem zamiast numeru i tytułu pisma podają tytuł wyboru wierszy i ich autora, jakby publikacja była samodzielnym tomikiem poezji ${ }^{\mathrm{I}}{ }^{4}$. Serie niekiedy zastępowały wręcz ukazujące się wcześniej czasopisma, w których prezentowano teksty literackie i teoretyczne powiązane z poezją i sztuką $\mathrm{z}$ kręgów pierwszej i drugiej awangardy ${ }^{\mathrm{I}}$. W sposób szczególny

I3 Szerzej o tym zagadnieniu piszę w artykule Konkretystyczne publikacje seryjne („Humanistyka XXI wieku” 2012, nr 1, http://www.humanistyka.edu.pl, dostęp: 6 maja 2014).

${ }_{\text {I4 }}$ Świadczą o tym zwłaszcza katalogi bibliotek, w których te same pozycje bywają klasyfikowane albo jako czasopisma, albo jako książki. Przykładowo w londyńskiej National Art Library wszystkie numery „,konkrete poesie / poesia concreta" można znaleźć tylko pod wspólnym tytułem jako czasopismo, podczas gdy w Deutsche Nationalbibliothek kolejnych numerów serii należy szukać pod osobnymi tytułami zbiorów, przykładowo numer 1 został skatalogowany jako książka Eugena Gomringera 5 mal 1 konstellation, numer 3 - jako antologia ideogramme $=$ idéogrammes $=$ ideograms.

Serie: „futura”, red. H. Mayer, edition hansjörg mayer, Stuttgart 1965-1968, nr 1-26; „rot”, red. M. Bense, E. Walther, edition rot, Stuttgart 1960-1997, nr 1-62; „konkrete poesie / poesia concreta”, red. E. Gomringer, eugen gomringer press, Frauenfeld 1960-1965, nr 1-10; , material”, red. D. Spoerri, Darmstadt 1958-1959, nr 1-5 (bez 4).

Informacje pochodzą m.in. z: edition und galerie hansjörg mayer oraz rot gesamtverzeichnis, w: Als Stuttgart Schule machte. Ein Internet-Reader, red. R. Döhl, J. Auer, F.W. Block, www.stuttgarter-schule.de, dostęp: 29 stycznia 2012. Zob. też: In Numbers: Serial Publications by Artists since 1955, red. P.E. Aarons, A. Roth, PPP Editions, Zürich 2009, s. 265-270; zbiory National Art Library w Londynie.

I5 Mam tu na myśli pismo ,augenblick” wychodzące w Stuttgarcie i zastąpione później przez „rot” oraz berneńskie pismo „spirale”, w którego działalność angażował się Gomringer, zanim stworzył „konkrete poesie / poesia concreta” (zob.: O. Herwig, Wortdesign. Eugen Gomringer und die Bildende Kunst, Iudi- 
serie pozwalały zaś na włączenie kolejnych publikowanych tekstów w myślenie o poezji konkretnej i jej satelitach - od samego początku wydawnictwa te obejmowały twórców różnych języków, dowodząc tym samym międzynarodowości wczesnego konkretyzmu. W numerze trzecim darmstadzkiego „material” znajdziemy emigranta z Ameryki, Emmetta Williamsa, a w numerze pierwszym - międzynarodowe grono poetów ${ }^{\mathrm{I}}$; $\mathrm{w}$ „konkrete poesie / poesia concreta" Gomringera można przeczytać Edwina Morgana, Szkota, oraz Ferreirę Gullara, Brazylijczyka ${ }^{17}$, dominują jednak autorzy niemieckojęzyczni ze Szwajcarii, Austrii i Niemiec ${ }^{18}$. Pojawiają się także reklamy. W stuttgarckiej „futurze" redagowanej przez Mayera ukazują się utwory Czechów i Szkotów ${ }^{\mathrm{I9}}$, a w „rot” Bensego i Walther, obok Brazylijczyków z grupy Noigandres, można znaleźć także zaskakujące nazwiska Francuzów: Jeana Geneta i Francisa Ponge'a ${ }^{20}$. Oczywiście nie znaczy to, że ich prace automatycznie stawały się poezją konkretną. Na pewno jednak sytuuje je w horyzoncie zainteresowań niemieckojęzycznych konkretystów, których program był znacznie ogólniejszym projektem odnowienia języka i literatury, niż chciałoby się go widzieć w krajach, gdzie poezja konkretna miała mniejsze znaczenie i sprowadzała się do gier $\mathrm{z}$ wizualnością.

Równie istotne było samo umiejscowienie i przygotowywanie serii konkretystycznych. Publikacje te stanowiły rezultat pracy niemieckojęzycznych edytorów i grafików oraz poetów, którzy decydowali się z nimi właśnie drukować swoje wiersze. Poezja konkretna oraz spowinowacona $\mathrm{z}$ nią twórczość i myśl eksperymentalna posiadały tu własny kanał komunikacyjny - swoich wydawców, żywo zainteresowanych tą problematyką i świadomie ją współtworzących. Nie bez powodu we wszystkich omawianych tu seriach konkretystów dominowały takie kroje jak Helvetica, Futura, a także notacja maszynopiśmienna ${ }^{21}$. Wraz $\mathrm{z}$ konse-

cum, München 2001, s. 121; Als Stuttgart Schule machte. Ein Internet-Reader, http://www.stuttgarter-schule.de, dostęp: 6 maja 2014).

${ }^{\text {I6 }} \mathrm{W}$ numerze pierwszym pojawili się autorzy pochodzący z kilku krajów, tacy jak Josef Albers, Louis Aragon, Helmut Heissenbüttel, Eugen Gomringer, Dieter Roth, Daniel Spoerri (zob. http://www.danielspoerri.org/), których eksperymenty artystyczne postanowiono ze sobą powiązać w tej chyba pierwszej antologii poezji konkretnej (wcześniejszej niż antologia z numeru „spirale” z 1960 r.)

${ }^{17}$ Odpowiednio w numerach 9 i 7 .

${ }^{18}$ Szwajcar: Gomringer; Niemcy: Heissenbütel i Bremer; Austriacy: Jandl, Rühm, Achleitner.

I9 Zob. numery 6, 7 i 20.

${ }_{20}$ Zob. numery 3 i 30 .

${ }^{21}$ Wygląd maszynopisu mają wiersze z dwóch numerów „konkrete poesie / poesia concreta”, poświęconych utworom Edwina Morgana i Ernsta Jandla 
kwentnym stosowaniem samych małych liter i asymetrycznym składem wszystkie te publikacje wspierały i współkształtowały program konkretyzmu, umieszczając go nie tylko na tle debat literackich, lecz także w kontekście poszukiwań typograficznych $^{22}$. Modernistyczna poezja wymagała modernistycznego projektowania, konstruktywistyczne teksty - geometrii, pomysły poetyckie inspirowane rozwojem techniki, teorii informacji, lingwistyki - maszynowego wyglądu. Do tego dochodziły zaś jeszcze inne czynniki, widoczne choćby na okładce „rot”: nieoczywisty stosunek do kultury masowej, lewicowe poglądy oraz kontynuowanie wybranych tradycji przedwojennej awangardy.

Tak ukształtowane serie łączyły w sobie dwa aspekty funkcjonowania poezji konkretnej. Po pierwsze, był to jej wymiar programowy, w jakimś stopniu realizowany przez poetów publikujących w seriach i czasopismach współtworzonych przez konkretystów, lecz także obecny w wielu książkach wydawanych indywidualnie. Po drugie, zaznaczał się tu także jej wymiar grupowy, związany ze wspólnym działaniem twórców z różnych dyscyplin przy powstawaniu publikacji oraz z poszerzaniem ram tejże do całego cyklu zeszytów, do projektu rozciągniętego w czasie i angażującego wiele osób.

W tym drugim wymiarze Wirpsza okazuje się współtwórcą zbiorowo kształtowanej serii „rot”; w tym pierwszym, programowym, sam nie do końca wpisuje się w wyznaczniki konkretyzmu, choć wyrażając zgodę na seryjny wygląd swojej książki, zbliża ją do tegoż programu. Bo też trzeba pamiętać, że istotny postulat konkretystów stanowiło uwypuklanie roli zapisu, przestrzeni, kartki czy kroju pisma w kreowaniu znaczeń tekstu. Takie zabiegi wizualne w pełni dostępne zaś były tylko osobom związanym bliżej z przedsięwzięciami drukarskimi czy przynajmniej z publikacjami seryjnymi. Współtworzone wydawnictwa umożliwiały więc całościową realizację postulatów konkretyzmu. Zwłaszcza że dla konkretystów uwypuklanie wyglądu publikacji nie oznaczało zwykle ścisłego i ostatecznego powiązania danych słów z jednym kształtem graficznym. Wręcz przeciwnie, wprowadzanie zmian

(nr 8 i 9) oraz wspominane konkretionen Emmetta Williamsa z „material”. Seria „rot” posługuje się Futurą i Helveticą, „futura” - Futurą, „konkrete poesie” Helveticą.

${ }^{22}$ Ważną rolę odegrały tu przekonania Maksa Billa i całego środowiska kierowanej przez niego Wyższej Szkoły Projektowania w Ulm, wywodzącej swoje koncepcje z Bauhausu. Ulm było przez jakiś czas środowiskiem artystyczno-naukowym zarówno Gomringera, jak i Bensego. Na podstawie polemik Billa z powojennymi poglądami Jana Tschicholda możemy się przekonać, że typografia była dla tych artystów sprawą niebagatelną (zob.: konkretepoesie. deutschsprachige authoren, red. E. Gomringer, Reclam, Stuttgart 2001, s. 19, 52; M. Bill, op.cit.). 
w tym zakresie - wydawanie tych samych utworów w różnych układach, książkach, oficynach i opracowaniach typograficznych - pozwalało wydobywać wyrazistość semantyki druku ${ }^{23}$. Na tym tle nie tyle sam wiersz, ile gest poety zdecydowanie mieści się w orbicie ruchu konkretystycznego. Za ślad takiego właśnie odczytania tomiku Wirpszy można zaś uznać podpis „Konkrete Poesie" umieszczony przy tejże książce w ofercie jednego z niemieckich antykwariatów ${ }^{24}$.

\section{Wirpsza a Grupa Stuttgarcka}

W Polsce podstawowym sposobem lektury utworów Witolda Wirpszy powstających w latach 60 . pozostaje czytanie ich jako poezji lingwistycznej i literaturoznawczej, wymienianej zwykle razem z tekstami Mirona Białoszewskiego i Tymoteusza Karpowicza ${ }^{25}$. Twórczość Wirpszy rzeczywiście wpisuje się w wyznaczniki polskiego nurtu lingwistycznego, jakkolwiek niewystarczające do oddania pełni poetyki tego autora. Co prawda niektórzy badacze zestawiali już poezję lingwistyczną z poezją konkretną, w wymiarze ograniczonym jednak analizowanymi przez nich pracami ${ }^{26}$. Z kolei na poziomie tak ogólnych spostrze-

${ }^{23} \mathrm{Na}$ przykład w drugim numerze "konkrete poesie / poesia concreta” mamy Helmuta Heissenbüttela text obne komma (,tekst bez przecinka”) z adnotacją, że drukowano go już wcześniej w „augenblicku”, ale tu pojawia się w innym opracowaniu typograficznym, które pozwala czytać go w nowych powiązaniach. Eugen Gomringer nieraz publikował te same wiersze w różnych tomikach utworów wybranych i zebranych i w różnych oficynach - zachowywał jednak zwykle krój pisma (Helvetica) i nie stosował wielkich liter. Warto zauważyć, że ze względu na tego rodzaju praktyki oraz zespołowe przygotowanie publikacji omawiane tu serie i książki nie mieszczą się w ramach popularyzowanej ostatnio w Polsce kategorii liberatury, opartej na idei jedynego, autorskiego projektu. Poezja konkretna - podobnie zresztą jak wiele przykładów awangardowych - podkreśla raczej niemożliwe do uniknięcia uwikłanie w materialność i jej semantykę każdego tekstu pisanego (por. np. Z. Fajfer, Liberatura. Teksty zebrane z lat 1999-2009, red. K. Bazarnik, Ha!art, Kraków 2010).

${ }_{24}$ To opis zamieszczony przez Buchhandlung und Antiquariat Dr. Wohlers \& Co na stronie http: / / www.abebooks.co.uk, dostęp: 8 marca 2012.

25 Do poezji lingwistycznej zaliczyli twórczość Wirpszy choćby Edward Balcerzan i Stanisław Barańczak. O poezji Wirpszy jako teorii poezji zestawianej właśnie z twórczością Białoszewskiego i Karpowicza pisała we wspomnianym już tomie Joanna Grądziel-Wójcik. Jako przykład literatury literaturoznawczej poezja Wirpszy pojawia się obok Karpowicza (zob. D. Ulicka, Literaturoznawcze dyskursy możliwe. Studia z dziejów nowoczesnej teorii literatury w Europie Środkowo-Wschodniej, Universitas, Kraków 2007, s. 26).

${ }^{26}$ Przykłady poezji Białoszewskiego zestawiał z konkretyzmem Tadeusz Sławek, o powiązaniach polskiego konkretyzmu z lingwizmem (np. o fascynacji Stanisława Dróżdża Karpowiczem i Białoszewskim) wspomina Małgorzata Dawidek-Gryglicka, o konkretyzmie w kontekście lingwizmu piszą Marianna 
żeń trzeba by te dwa nurty sprowadzić do wspólnych dla obu tych kierunków poszukiwań metajęzykowych i metaliterackich, do kolejnych wersji literatury eksperymentalnej i powrotu do awangardy. Traktowane ahistorycznie, poza kontekstami powstania, zupełnie różnymi nawet dla samego konkretyzmu w wersji polskiej i niemieckiej, podobieństwa te nie mogą wyjaśnić powiązań Wirpszy i serii „rot”. Zamiast tego należałoby przyjrzeć się raczej poszczególnym projektom i koncepcjom poetyckim Wirpszy oraz konkretystów niemieckojęzycznych, zwłaszcza związanych ze Stuttgartem.

Przede wszystkim trzeba powiedzieć, że Witold Wirpsza był autorem pierwszej chyba $\mathrm{w}$ języku polskim prezentacji poezji konkretnej. W roku $1966 \mathrm{w}$ przeglądzie zagranicznym czasopisma „Poezja” ukazał się jego artykuł zatytułowany Niemiecka Republika Federalna. Tekst wskazywał na nowości z literatury niemieckiej, tyle że wybiórczo - gdyż był ograniczony do recenzji dwóch monograficznych numerów periodyku „Sprache im technischen Zeitalter" poświęconych poezji konkretnej ${ }^{27}$. W artykule Wirpsza zwracał uwagę na metajęzykowość tej poezji, podawał przykłady omawianej twórczości, a także nadmieniał o autorach ze środowiska stuttgarckiego - rok przed opublikowaniem w Stuttgarcie własnego tomiku wierszy.

Kontekst Stuttgartu nieodłącznie wiązał się zaś z nazwiskiem Maksa Bensego, semiotyka, filozofa, estetyka, a także poety konkretnego, który w Technicznej Szkole Wyższej w Stuttgarcie, przekształconej potem w Uniwersytet Stuttgarcki, stworzył cały zespół zajmujący się naukowymi badaniami semiotycznymi, a także działalnością wydawniczą, translatorską, artystyczną

Bocian i Leszek Szaruga. Przykłady te dotyczą jednak głównie polskiej wersji poezji konkretnej (zob.: T. Sławek, Między literami. Szkice o poezji konkretnej, Wydawnictwo Dolnośląskie, Wrocław 1989, s. 48-49; M. Dawidek-Gryglicka, Historia tekstu wizualnego. Polska po 1967 roku, Korporacja Ha! art - Muzeum Współczesne Wrocław, Kraków - Wrocław 2012, s. 120; M. Bocian, Przestrzeń w poezji konkretnej: ogólnopolskie sympozjum nt. poezji konkretnej, Bydgoszcz, 20-21 X 1979: materiaby teoretyczne, Towarzystwo Przyjaciół Sztuki, Wydział Kultury i Sztuki UM, Miejska Poradnia Instrukcyjno-Metodyczna, Bydgoszcz 1979, s. 32-33; L. Szaruga, Przestrzenie stowa: eseje, Wydawnictwo Baran i Suszczyński, Kraków 2002, s. 73-75). O poetykach Dróżdża, Grześczaka i Białoszewskiego, opatrywanych, nie wiadomo dlaczego angielskim terminem concrete verse, pisał w dość kontrowersyjny sposób Jacek Wesołowski (zob. J. Wesołowski, Trzy polskie poetyki ,concrete verse”. Dróżḋ, Grześczak, Białoszeweski, „Odra” 2005, nr 3, s. 50-55).

27 W. Wirpsza, Niemiecka Republika Federalna, „Poezja” 1966, nr 4. Warto tu zauważyć, że w artykule pomylono wiersze Clausa Bremera i Eugena Gomringera, przypisane tym twórcom odwrotnie niż w rzeczywistości (choć w omawianym numerze 15, „Sprache im technischen Zeitalter” z roku 1965, zrobiono to poprawnie). 
i poetycką ${ }^{28}$. Stworzony wokół Bensego krąg akademicki, i szerzej: naukowo-artystyczny, można by nazywać odpowiednio Szkołą Stuttgarcką i Grupą Stuttgarcką ${ }^{29}$. Do pierwszej trzeba by zaliczyć badaczkę Elisabeth Walther, do drugiej zaś - Hansjörga Mayera, typografa, drukarza, artystę. Istotą środowiska stuttgarckiego była jednak wzajemna współpraca i przenikanie się obu sfer. Koncepcje tekstu Bensego wspierały się na ówcześnie tworzonych utworach eksperymentalnych, a same książki filozofa, choć sformalizowane i zmatematyzowane, nieraz miały postać publikacji artystycznych ${ }^{\circ}$. Właśnie ową „artystyczną niefrasobliwość" zarzucał Teorii tekstu Bensego jeden z pierwszych polskich recenzentów prac tego autora (w „Pamiętniku Literackim”

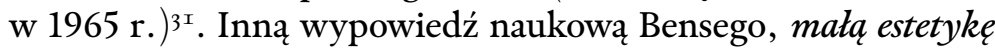
abstrakcyjna, wydano zresztą w serii „rot” obok wielu tekstów literackich w 1969 r. ${ }^{2}$, dwa lata po tomiku Wirpszy. To na podstawie tej odrębnej, choć wpisanej w porządek serii, książeczki Bensego z "rot” powstało także jej polskie tłumaczenie, dokonane przez - nomen omen - Witolda Wirpszę, opatrzone wstępem Edwarda Balcerzana i opublikowane w 1970 r. na łamach „Nurtu” ${ }^{33}$. Wstęp Balcerzana zachęcał do samodzielnej, uważnej lektury tekstu Bensego, znanego ówcześnie w Polsce przede wszystkim z nie zawsze przychylnych opracowań, samo zaś nietypowe wydanie pracy Bensego w oryginale - pojedynczy zeszyt serii „rot” - nazwał badacz „książeczką”. Tym samym seria „rot” została przedstawiona polskim czytelnikom.

Powiązania między Wirpszą a Bensem znajdowały odzwierciedlenie nie tylko we wzajemnych publikacjach i przyjaźni obu

${ }^{28}$ Zob. informacje wstępne w: M. Bense, w: Świat przez pryzmat znaku, tłum. J. Garewicz, wstęp H. Buczyńska-Garewicz, PIW, Warszawa 1980. Zob. też R. Döhl, Der Kreis um Max Bense, w: Als Stuttgart Schule machte.

${ }_{29}$ R. Döhl, Stuttgarter Gruppe oder Einkreisung einer Legende, w: Als Stuttgart Schule machte.

$3^{\circ}$ Zob. np. M. Bense, Theorie der Texte. Eine Einfübrung in neuere Auffasungen und Methoden, faksymile książki z 1962, Ann Arbor, Michigan 1971. Odniesienia np. do poezji konkretnej Gomringera - zob. ibidem, s. 114. Warto Grupie Stuttgarckiej przyjrzeć się z perspektywy wywodu prowadzonego w przywoływanej już książce Literaturoznawcze dyskursy możliwe autorstwa Danuty Ulickiej. Działalność Grupy i samego Bensego potwierdza, jak uproszczone są głoszone do dziś przekonania o „czystości” ówczesnej nauki o literaturze oraz o antagonizmie nauki i sztuki.

${ }^{3^{\mathrm{I}}}$ W. Skalmowski, Max Bense, Theorie der Texte. Eine Einfübrung in neuere Auffasungen und Methoden, Köln 1962, „Pamiętnik Literacki” 1965, nr 1-2, s. $652-653$ i 662.

${ }^{32}$ M. Bense, kleine abstrakte ästhetik, „rot” 38, Stuttgart 1969.

33 M. Bense, mała estetyka abstrakcyjna, thum. W. Wirpsza, „Nurt” 1970, nr 3 . 
twórców ${ }^{34}$, lecz także w ich koncepcjach tekstu literackiego. Wirpszowy postulat oceniania dzieł sztuki nie ze względu na ich wymiar emocjonalny i zmysłowy, ale na ich konstrukcję 35 , przypomina spostrzeżenia Bensego. Stwierdzenie Wirpszy, że „źródłem zarówno aktu poznawczego, jak i doznania estetycznego jest informacja" ${ }^{6}{ }^{6}$, współgra z kreowaną przez Bensego estetyką informacji, podobnie jak zainteresowanie znakowym wymiarem tekstu i traktowanie poezji jako obserwacji języka ${ }^{37}$. Obydwoje też - i Bense, i Wirpsza - przypisywali poezji pewne cele poznawcze, ograniczone do poznania samych możliwości mowy i zapisu, do struktur myślenia zakodowanych w języku. Z kolei teksty teoretyczne Wirpszy oraz niektóre manifesty Bensego nie mieściły się w ówczesnym trybie naukowym, korzystając z części dobrodziejstw dyskursu literackiego.

Zainteresowania Wirpszy nie ograniczały się jednak do naukowego kontekstu stuttgarckiego, lecz obejmowały całą szeroko pojętą niemieckojęzyczną poezję konkretną. Autor znał się z austriackim poetą Ernstem Jandlem i zafascynowany był książkami niemieckiego twórcy Heinricha Heissenbüttela, a w późniejszych latach wykładał poezję konkretną na Uniwersytecie Technicznym w Berlinie Zachodnim ${ }^{3}$. O poezji konkretnej wspominał także w opublikowanym w roku 1982 artykule In dubio pro arte, gdzie nie tylko ukazywał jej rolę, zestawiając ją z lingwizmem i twórczością awangard, ale także i bronił jej przed oskarżeniami o bycie sztuką dla sztuki 39 .

Nie można również zapomnieć o związkach twórczości literackiej Wirpszy z programem realizowanym przez niemieckich poetów konkretnych. To prawda, że lingwizm w Wirpszowej odmianie odznaczał się znacznie mniejszą redukcją języka, niż to miało miejsce w większości utworów poezji konkretnej. Składnia i jej zaskakujące meandry pozwalały za to przekroczyć ograniczenia typowego konkretyzmu, w postaci znanej choćby z wierszy Gomringera. Ograniczenie to wskazywał już w 1969 r.

34 Informacja pochodzi od Profesora Leszka Szarugi. Warto także wspomnieć tekst napisany przez Wirpszę do księgi dedykowanej Maksowi Bensemu: Muster möglicher Welten: Eine Antbologie für Max Bense, red. E. Walther, L. Harig, Limes-Verlag, Wiesbaden 1970.

35 W. Wirpsza, Gra znaczeń. Szkice literackie, PIW, Warszawa 1965, s. 211.

${ }^{36}$ Ibidem, s. 220.

37 Zob. ibidem, s. 252, a także 221. Por.: M. Bense, Theorie der Texte, s. 40, 57, 59; idem, Die Realität der Literatur. Autboren und ibre Texte, Kiepenhauer und Witsch, Köln 1971, s. 97.

$3^{8}$ Informacja pochodzi od Profesora Leszka Szarugi.

39 Zob. W. Wirpsza, Gra znaczeń. Przerób, Instytut Mikołowski, Mikołów 2008, s. 208-209. 
Heinrich Heissenbüttel ${ }^{40}$, sam obficie korzystający z możliwości niemieckiej składni i fleksji, co pozwalało mu na wprowadzenie krytycznego, a nie tylko afirmatywnego stosunku do języka. Relacje twórczości Heissenbüttela i Wirpszy, których zdają się łączyć nie tylko powierzchowne podobieństwa w podejściu do mowy, wciąż oczekują zresztą na zbadanie. W tym miejscu warto zaznaczyć, że Heissenbüttel nie był konkretystą sensu stricto: choć nieraz zaliczano go do konkretyzmu ${ }^{4 \mathrm{I}}$, sam autor nie aprobował tej etykietki.

W wierszach Wirpszy można wreszcie znaleźć pewne podobieństwa do konkretystów w zakresie poszukiwań nowych sposobów zapisu i eksploracji przestrzeni strony. Zwłaszcza teksty dobrane do tomiku brucbsünden und todstücke przypominają o zainteresowaniach poety wizualną stroną utworu ${ }^{42}$. Warto porównać sposób wykorzystania przestrzeni w niemieckim tomiku Wirpszy z metodami widocznymi u innych poetów związanych ze Stuttgartem, choćby i w samym tylko 1967 r. Takie zestawienie pozwoli spojrzeć na Wirpszę w perspektywie innej niż polski kontekst historycznoliteracki - w kontekście zaproponowanym przez samego twórcę.

\section{Inne książki}

Do innych stuttgarckich publikacji wydanych w roku 1967 należy trzydziesty drugi numer serii „rot”, poświęcony tym razem tekstom Dietera Rota. Projekt typograficzny tej książki jest niemal identyczny z brucbsünden und todstücke ${ }^{43}$, jeśliby wziąć pod uwagę format, krój pisma, okładkę i brak wielkich liter. Obecna już w tomiku Wirpszy zabawa z konwencjami pogrubiania tekstu jest tutaj posunięta jeszcze dalej. O ile u Wirpszy teksty właściwe wierszy są właśnie w ten sposób wyróżnione (w przeciwieństwie do ich tytułów, czyli inaczej niż można by się spodziewać), o tyle u Rota wszystkie strony podzielono na część górną i dolną - co pozwala na jednoczesne prowadzenie dwóch odrębnych cykli tekstów: $\mathrm{u}$ góry i u dołu kartki. W górnym cyklu pogrubienia

$4^{\circ} \mathrm{H}$. Heissenbüttel, einleitung, w: E. Gomringer, worte sind schatten: die konstellationen 1951-1968, red. H. Heissenbüttel, Rowohlt, Reinbek bei Hamburg 1969, s. 19-20.

${ }_{4 \mathrm{I}}$ Zob. choćby twórczość autora umieszczoną w: konkretepoesie: deutschsprachige autoren: anthologie, red. E. Gomringer, Reclam, Stuttgart 2009 (wydanie pierwsze: 1972).

$4^{2}$ Por. także W. Wirpsza, Komentarze do fotografii ,The Family of Man”, Wydawnictwo Literackie, Kraków 1962.

43 D. Rot, 80 wolken, red. M. Bense, E. Walther, „rot” 32, Stuttgart 1967. 
są analogiczne do Wirpszowych, w dolnym zaś wyeksponowano tytuły, a nie wiersze. Takie zestawienie na jednej stronie dwóch opracowań graficznych wskazuje nie tylko na rolę typografii, lecz także na jej autora. Twórcą tej łączącej obie książki tekstowej gry musiał być bowiem drukujący oba tomiki Mayer (a nie poeci, Wirpsza czy Rot). Pewne podobieństwa występują też na płaszczyźnie języka. Nadany przez Rota tytuł jego zbiorku: 80 wolken, czyli 80 chmur, można odnieść do ponumerowanych tekstów zawartych $\mathrm{w}$ tomiku, które $\mathrm{w}$ sumie dają właśnie zapisaną w tytule liczbę. Każdy z utworów okazuje się zatem porównany do chmury. Widać tu pewne podobieństwo do Wirpszowych bruchsünden und todstücke, w retranslacji ułamanych grzechów $i$ śmiertelnych fragmentów, a w oryginale Siedmiu ułomków głównych. Tytułowe „ułomki” czy „fragmenty” stają się także określeniami wszystkich pomieszczonych w książce tekstów. Motywacji i dla „ułomków”, i dla „chmur” można zaś szukać w wyglądzie wierszy.

Innym przykładem stuttgarckiej publikacji z 1967 r. jest dwudziesty numer redagowanej przez Mayera serii „futura” ${ }^{44}$. Każdy egzemplarz tej serii to, inaczej niż w „rot”, nie zeszyt, lecz złożony arkusz papieru. Numer dwudziesty poświęcono zaś emergent poems Edwina Morgana, jednego z głównych szkockich poetów konkretnych. W serii tej wiersze nieraz pozostawały w oryginalnych wersjach językowych, nietłumaczone na niemiecki. Tak stało się także z utworami Morgana, które, podobnie jak wiersze Wirpszy, opierają się na wykorzystaniu spacji i wymazywania tekstu. Warto porównać technikę Morgana z metodą Wirpszy. Żadna $\mathrm{z}$ nich bowiem nie stosuje spacji jako ikonicznego znaku bieli, u obu twórców pustka sygnalizuje pewien brak, zamazanie słów czy też ich niewystarczalność. Różnica polega na tym, że Wirpsza na takim zabiegu poprzestaje, a brakujące wyrazy czasem podaje w kolejnej iteracji danej frazy, podczas gdy u Morgana wyrywkowe fragmenty zdań, pozostawione $\mathrm{z}$ nich wybrane litery lub słowa, tworzą własne dodatkowe sensy, układają się w nowe wypowiedzi. U Morgana teksty są także bardziej zdyscyplinowane - $\mathrm{w}$ emergent poems jeden krótki cytat, na którym kończy się dany utwór, jest we wcześniejszych linijkach w różnym stopniu wymazany i powtórzony. Teksty nie wykraczają jednak poza przekształcenia pojedynczego cytatu. Sam tytuł arkusza Mograna podkreśla zresztą możliwość pojawienia się utworu w utworze, nagłego zrodzenia się tekstu $\mathrm{z}$ wymazanych urywków, a także ostatecznie wyłaniającej się w ostatniej linii pełnej postaci cytatu.

44 E. Morgan, emergent poems, red. H. Mayer, „futura” 20, Stuttgart 1967. 
U Wirpszy natomiast opowieść, choć mocno pocięta, jest meandrycznie rozwijana przez cały wiersz - tytuły i teksty podkreślają zaś ułomność, niepełność przekazu.

Środowisko stuttgarckie, skupione na eksperymentach literackich i naukowych, nie wykluczało wykorzystania w publikacjach spacji i redukcji zapisu w celu mówienia - czy raczej milczenia o pozaludzkim i pozajęzykowym. U Morgana pierwszy utwór $\mathrm{z}$ cyklu jest przewrotnie zatytułowany message clear. „Jasna, klarowna wiadomość" to wiadomość optycznie wyczyszczona z wielu liter, ale przez to trudna w lekturze, nieprzejrzysta. Dzięki temu zabiegowi wyeksponowano wielość i tajemnicę sensów zawartych w biblijnym cytacie, który kończy wiersz. Zanim dotrzemy do końcowego „i am the resurrection and the life” (J 11,25), wybrane litery tego zdania pozostawione we wcześniejszych wersach składają się we frazy takie jak: „i am the sun”, „i am the son” czy „i am the erect one” ${ }^{45}$. Ostatecznie zatem wizualna trudność w lekturze odzwierciedla niepojmowalność przekazu, nieprzejrzystość staje się swoistą przejrzystością ${ }^{46}$. Tymczasem w książce Wirpszy już w tytule tomu pojawia się problematyka grzechu i ułomności, zwłaszcza w polskiej wersji tej nazwy pobrzmiewająca aluzją do biblijnych koszy ułomków ${ }^{47}$. U obu poetów próby mówienia pomimo ograniczeń języka, choć bez ukrywania cząstkowości zapisanych prawd, są przedstawiane nieomal jak cud: jak nagle wyłaniające się wiersze, jak cudownie powstałe odłamki. Przypadkowe sąsiedztwo publikacji tych autorów w dwóch stuttgarckich seriach z roku 1967 pozwala zauważyć zaskakujące powinowactwa pomiędzy ich tekstami. Paradoksalnie sąsiedztwo to ukazuje, że seryjne właściwości projektów graficznych moga wzmocnić przekaz nawet takich utworów Morgana i Wirpszy, jak wspominane powyżej. Nachalna materialność, broszurowość, typograficzna namacalność tomiku Wirpszy zdaje się lepiej niż przezroczysta ponadczasowość polskich wydawnictw ujawniać współczesną twarz ułomnego, cząstkowego języka. Natomiast maszynowość pisma i wizualny porządek powtarzalnych tekstów $\mathrm{z}$,futury”, kolejne linijki Morgana z literami umieszczonymi dokładnie jedna pod drugą, wzmagają wrażenie permutacyjnej,

45 Chodzi zatem o cytat: „Ja jestem zmartwychwstaniem i życiem” oraz o frazy: ,jestem słońcem”, , ,jestem synem”, ,jestem wyprostowany/prawy” thum. A.K.

${ }^{46}$ Dla przejrzystości tego wywodu trzeba jednak dodać, że wśród źródeł cytatów przetwarzanych w emergent poems są także Brecht i Manifest komunistyczny. Podobną uwagą należy opatrzeć i stuttgarckie teksty Wirpszy, które z pewnością nie są poświęcone głównie Biblii ani metafizyce.

47 Szerzej piszę o tym we wspominanym artykule Book of translations as a self-commentary. 
matematycznej nieskończoności sensów, o których język próbuje zaledwie wspominać. $\mathrm{W}$ ten sposób środki nowoczesnego niemieckiego projektowania graficznego oraz estetyka poetów eksperymentalnych z Polski i Szkocji spotykają się w Stuttgarcie z tamtejszymi, obficie korzystającymi z wizualności tekstu, projektami konkretystów.

Kontekstem dla publikacji Wirpszy może być bowiem także uderzający swoim wyglądem tomik bedepequ Reinharda Döhla ${ }^{4}$. $\mathrm{Z}$ perspektywy takich jak bedepequ prac niemieckojęzycznego konkretyzmu książka Wirpszy z serii „rot” zdaje się niemal konwencjonalnie pomyślanym zbiorem. W porównaniu z polskimi ówczesnymi wydaniami literatury eksperymentalnej „,rot” można rzeczywiście uznać za niezwykłe. W tym samym czasie w Niemczech opublikowano jednak bedepequ Döhla w słynnej hansjörg mayer edition w bardzo dużym kwadratowym formacie, skoroszytowym kodeksie i jarzeniowych odcieniach różu i niebieskiego. Utwory Döhla sprowadzają się już do samych układów liter: b, d, p i q, które w odpowiednio dobranym kroju okazują się swoimi odbiciami symetrycznymi. Tytuł książki to natomiast zapis typowej wymowy tego ciagu spółgłosek. Wieloznaczność prac Döhla ściśle zależy od współpracy z typografem i sprowadzona zostaje do najniższego poziomu zapisu, bo wśród liter stawianych pionowo, poziomo i do góry nogami nie sposób odróżnić p od d.

Na koniec warto także wspomnieć o opublikowanym w $1967 \mathrm{r}$. tomiku Hansjörga Mayera. Mam tu na myśli jego typoaktionen, wydany we Frankfurcie nad Menem w oficynie typos verlag, w której aktywność angażował się z kolei inny poeta konkretny, Franz Mon ${ }^{49}$. Książka typoaktionen traktuje litery już niemal jak grafikę - ich zagęszczenie w niektórych miejscach kartek daje efekt roju much lecących do rogu strony. Publikacja mieści się jednak w ciągle poszerzanych przez konkretystów konceptualnych ramach książki drukowanej $5^{\circ}$.

Z perspektywy stuttgarckiej wydanie książki Wirpszy w serii „rot” można uznać za efekt swego rodzaju domestykacji. Na prze-

$4^{8}$ R. Döhl, bedepequ, hansjörg mayer edition, Stuttgart 1967.

49 H. Mayer, typoaktionen, wstęp R. Döhl, typos verlag, Frankfurt 1967. O Franzu Monie - zob. np. konkrete poesie. deutschsprachige authoren, s. 99.

50 Poszerzanie granic książki w tym wypadku oznaczało także stworzenie publikacji składanej harmonijkowo (a nie kodeksowej), drukowanej na kartonie kredowym. 
kład utworów Wirpszy został nałożony typowy dla niemieckojęzycznego myślenia o poezji metajęzykowej i eksperymentalnej projekt wydawniczy książki. Jeśli jednak uznamy niemiecki tomik za autorski gest poety, za rodzaj aneksu do polskich wierszy, wtedy trzeba by raczej mówić o strategii wyobcowania. Publikacja książki w serii konkretystycznej pozwala bowiem polskim czytelnikom spojrzeć na Wirpszę jak na zagranicznego poetę z orbity niemieckojęzycznego konkretyzmu, umieszczonego w kontekście stuttgarckich zainteresowań i programów artystycznych oraz wydrukowanego $\mathrm{w}$ serii o właściwościach zupełnie obcych dla polskiego rynku wydawniczego lat $60.5^{\mathrm{I}}$.

Na koniec trzeba także podkreślić, że poza modyfikacją dotychczasowej recepcji poezji Wirpszy i zachętą do badań komparatystycznych tomik brucbsünden und todstücke stanowi korektę dotychczasowego obrazu polskiego uczestnictwa w międzynarodowym ruchu konkretystycznym. Dotąd za jedyny sygnał włączenia się Polaków w działalność ruchu uznawano wystawienie dwóch prac Stanisława Dróżdża na podsumowującej konkretyzm wystawie w Amsterdamie w 1970 r. ${ }^{52}$. Tymczasem okazuje się, że za wydarzenie inicjalne należałoby uznać wydanie poezji Wirpszy w stuttgarckiej serii „rot”, które miało miejsce trzy lata wcześniej.

${ }^{5}$ Dzięki publikacji zagranicznej i jej właściwościom mamy więc tutaj do czynienia także z jednym z nielicznych przykładów całościowego eksperymentalnego myślenia o poezji polskiej i jej prezentacji w pierwszych dekadach po wojnie. Tego rodzaju kontynuacje w większości przerwanych w Polsce praktyk awangardowych można też odnaleźć w innych zagranicznych ośrodkach, na przykład w Londynie, w wydawnictwie Gaberbocchus Press Franciszki i Stefana Themersonów, którzy poza twórczością własną opublikowali między innymi reprint Europy Sterna i Szczuki czy prace Kurta Schwittersa (zob. np. A. Dziadek, Themerson i Schwitters, „Teksty Drugie” 2006, nr 4). Wyrazisty, choć oddalony o dziesięciolecia powrót do wspólnego lingwistycznego i typograficznego eksperymentu obecny jest już w poezji neolingwistów warszawskich. Tomasz Cieślak-Sokołowski uznał tomik Marii Cyranowicz piaty element to fiksja za opóźniony powrót do awangardowej współpracy poetów i artystów (zob. T. Cieślak-Sokołowski, Moment lingwistyczny: o wczesnym pisarstwie Ryszarda Krynickiego i Stanistawa Barańczaka, Universitas, Kraków 2011, s. 375-377).

${ }^{2}$ Oczywiście mówiąc o ruchu międzynarodowym, pomijam tutaj polską wrocławską szkołę poezji konkretnej z lat 70. i inne przejawy rozwoju rodzimej wersji konkretyzmu, powstające w pewnej izolacji od zagranicy oraz w czasie, gdy konkretyzm jako ruch przestał istnieć. Zakończenie działalności ruchu sytuuje się zwykle na początku lat 70., a za podsumowanie konkretyzmu uznaje się właśnie wspomnianą wystawę w Amsterdamie (zob. klankteksten - ? konkrete poëzie - visuelle teksten, Stedelijk Museum Catalogues, Amsterdam 1970, s. 132; zob. też M. Dawidek-Gryglicka, op.cit., s. 81). 


\section{ALEKSANDRA KREMER \\ Wirpsza in German tranlation, or from lingualism to con- cretism}

The article discusses bruchsünden und todstücke, a book of selected poems by Witold Wirpsza, translated into German by Maria Kurecka. The book was published in 1967 in the "rot" series published in Stuttgart and edited by Max Bense and Elisabeth Walther, with typography by Hansjörg Mayer. The article demonstrates how the peculiar design of the book, as well as the connotations of the publishing series, and Wirpsza's interests, allow us to read the book as a translation of a Polish image of language poetry into a German concept of experimental poetry book, especially in concrete poetry.

Keywords: Witold Wirpsza, concrete poetry, language poetry, poetry book, Stuttgart.

Aleksandra Kremer - doktor, asystentka w Instytucie Literatury Polskiej UW. Ukończyła polonistykę i anglistykę na UW oraz literaturę europejską w Cambridge. W roku 2013 obroniła z wyróżnieniem doktorat poświęcony książkom poezji konkretnej. Współredaktorka zeszytu monograficznego „Prac Filologicznych. Literaturoznawstwa" (2013, nr 3, cz. 1: Sources of Verse). e-mail: olakremer@wp.pl 